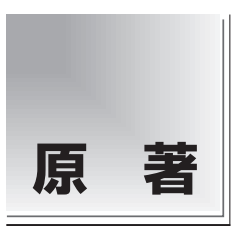

論文受付

2011 年 10 月 28 日

論文受理

2012 年 2 月 23 日

Code No. 890

\section{イメージングプレートの放射能污染による 黒点計数法の開発}

\author{
林 裕晃 $^{1} \quad$ 西原貞光 $^{1} \quad$ 小沼洋治 ${ }^{2}$ \\ 1 徳島大学大学院ヘルスバイオサイエンス研究部 \\ 2 労働者健康福祉機構鹿島労災病院放射線科
}

\section{緒 言}

2011 年春の東日本大震災によって福島第一原子力発 電所が被災し, 放射性同位元素(radioisotopes; RI)が環 境中に放出された。診療現場では，X線検出器 (imaging plate; IP)にRI が付着し, 未露光の IP にも黒点が生じ る現象が見られるようになった。本学会では, IP を利 用した環境モニタリングの試みや黒点の除染に関する 活動が行われている1 3)。これらの研究では, 污染の度 合いや除染の効果を定量化するための黒点の計数手法 が必要である。

RI は限りなく小さい点線源であり, 埃などに付着し て IPを污染させている. したがって, IP の画素サイズ よりもはるかに小さい点に局所的に RI が存在する可能
性が高い. この状態で長時間露光が行われると, 中心 となる画素とその周辺の画素にエネルギー付与が行わ

れ, 結果として黒点が出現すると考えられる.

従来の画像処理法において，このような RI の黒点発 生機序に基ついた概念で黒点部分を判定・検出した手 法は，われわれが調べた限りでは見当たらない. そこ で，(1)黑点中心候補を検出するための論理，(2)黑点 として判定するための条件，を考案しプログラムを開発 した.

\section{1. 方 法}

\section{1-1 解析した画像データ}

使用したディジタル画像装置(computed radiography;

\title{
Development of Counting Method of Black Spots Caused by the Radioactive Contaminations on the Imaging Plate
}

\author{
Hiroaki Hayashi, ${ }^{1}$ Sadamitsu Nishihara, ${ }^{1}$ and Yoji Onuma ${ }^{2}$ \\ ${ }^{1}$ Institute of Health Bioscience, The University of Tokushima Graduate School \\ ${ }^{2}$ Radiology Department of Kashima Rosai Hospital of Japan Labour Health and Welfare Organization
}

Received October 28, 2011; Revision accepted February 23, 2012

Code No. 890

\section{Summary}

Due to accidents of the nuclear power plants in Fukushima prefecture, a lot of radioisotopes were diffused into the environment. They adhered onto the surface of the X-ray detector (imaging plate; IP) and many black spots were seen on the medical images. The process to count them is important to evaluate the degree of contamination and/or removal. In this study, we aimed to develop a counting method for black spots. Based on the analysis of the medical images having black spots, we summarized that areas affected by the certain black spots were limited to the eight pixels surrounding the most intensive pixel. The newly developed counting method was applied to these nine pixels $(3 \times 3$ pixels) and selection rules were based on the following two information: 1. differences between the digital value of the most intensive pixel and those of the surrounding eight pixels, and 2. total summation of the digital values in the nine pixels. The estimated image based on our method showed a good concordance with the original image. Therefore, we summarized that our counting method is a powerful tool for estimating numbers of black spots.

Key words: imaging plate, black spots counting, radioisotopes, decontamination

*Proceeding author 


\begin{tabular}{|l|l|l|l|l|l|l|l|l|l|l|l|l|}
\hline 83 & 83 & 83 & 83 & 83 & 83 & 83 & 83 & 83 & 83 & 83 & 83 & 83 \\
\hline 83 & 83 & 83 & 83 & 83 & 83 & 83 & 83 & 83 & 83 & 83 & 83 & 83 \\
\hline 83 & 83 & 83 & 83 & 83 & 83 & 83 & 83 & 83 & 83 & 83 & 83 & 83 \\
\hline 83 & 83 & 83 & 83 & 83 & 83 & 83 & 83 & 83 & 98 & 234 & 112 & 83 \\
\hline 83 & 83 & 83 & 83 & 83 & 83 & 83 & 83 & 83 & 135 & 287 & 129 & 83 \\
\hline 83 & 83 & 83 & 83 & 83 & 83 & 83 & 83 & 83 & 83 & 98 & 85 & 83 \\
\hline 83 & 83 & 83 & 83 & 83 & 83 & 83 & 83 & 83 & 83 & 83 & 83 & 83 \\
\hline 83 & 83 & 83 & 83 & 83 & 83 & 83 & 83 & 83 & 83 & 83 & 83 & 83 \\
\hline 83 & 83 & 83 & 83 & 83 & 83 & 83 & 83 & 83 & 83 & 83 & 83 & 83 \\
\hline 83 & 83 & 83 & 83 & 83 & 83 & 83 & 83 & 83 & 83 & 83 & 83 & 83 \\
\hline 83 & 83 & 83 & 83 & 83 & 125 & 92 & 83 & 83 & 83 & 83 & 83 & 83 \\
\hline 83 & 83 & 83 & 83 & 199 & 273 & 119 & 83 & 83 & 83 & 83 & 83 & 83 \\
\hline 83 & 83 & 83 & 83 & 157 & 206 & 110 & 89 & 83 & 83 & 83 & 83 & 83 \\
\hline 83 & 83 & 83 & 84 & 83 & 83 & 83 & 83 & 83 & 83 & 83 & 83 & 83 \\
\hline 83 & 83 & 83 & 83 & 83 & 83 & 83 & 83 & 83 & 83 & 83 & 83 & 83 \\
\hline 83 & 83 & 83 & 83 & 83 & 83 & 83 & 83 & 83 & 83 & 83 & 83 & 83 \\
\hline 83 & 83 & 83 & 83 & 83 & 83 & 83 & 83 & 83 & 83 & 83 & 83 & 83 \\
\hline 83 & 83 & 83 & 83 & 83 & 83 & 83 & 83 & 83 & 83 & 83 & 83 & 83 \\
\hline 83 & 83 & 83 & 83 & 83 & 83 & 83 & 83 & 83 & 83 & 83 & 83 & 83 \\
\hline
\end{tabular}

Fig. 1 An example of the black spots in the small region.

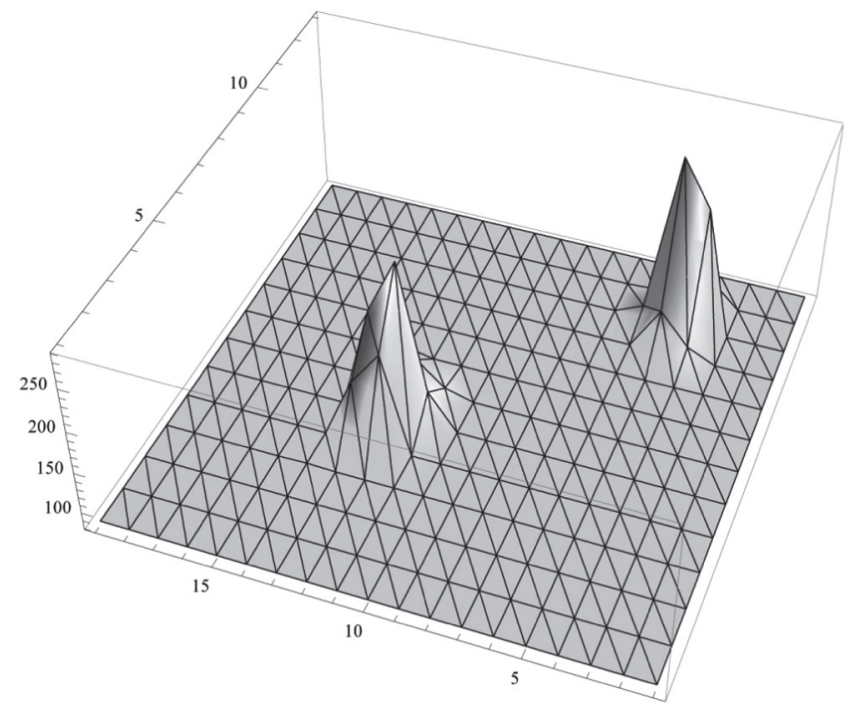

$a \mid b$
CR) は, 鹿島労災病院(茨城県)に設置されている立位 型の FCR システム (FCR5501plus，富士フイルムメディ カル社製)である。このシステムは，2 枚の IP(ST-55H1M，受像面の大きさ：広幅 $17 \times 17$ inch）を内蔵する夕 イプである. 2011 年 4 月 21 日の夕方から 22 日の朝方 までの約 12 時間利用していなかった 2 枚の IP に黒点 が発生していたそここで 2 枚のうちの 1 枚を本論文で 解析する，この画像は，IP 上に直接付着した RI が黒点 の主因となっていた2,3).

解析した画像の大きさは, $14 \times 14$ inchであり, $1760 \times 1760$ pixel $\doteqdot 3 \times 10^{6}$ 個のデイジタルデータで構成さ れている，画像を読み取るときの設定は， $S$ 值 $=200, L$ 值 $=4.0$ が固定されるモードである。これは，本学会が 立ち上げた「CR を用いた環境モニタリング研究班」が示 した処理モードと同じである1)。画像処理で得られた DICOM 画像は ImageJ $(\mathrm{NIH}, \mathrm{Ver} .1 .45)^{4)}$ を用いて，ディ ジタル值をテキストデータ形式で出力した。 このデータ を Mathematica(Wolfram Research, Inc.)で読み込み, 分布関数などの解析を行った.

Fig. 1 に，黒点が現れていた一部 $(13 \times 19$ pixel $)$ を拡大 して例示した. Fig. 1(a)はディジタル值のテキストデー 夕形式，(b)はディジタル值を三次元でプロットしたも のである. 画像の右上と中心付近にディジタル值が 250 を超える黒点の信号部分を確認できる.

\section{1-2 黒点の計数法}

1-2-1で黒点候補を検出する方法を示す。ここでいう 検出とは，広がりをもった黒点の中心座標を判定するた めの方法である. Fig. 1 の例では, 多くの画素に均一に
表れている 83 がバックグラウンドで，左下の画素に見 える $84(=83+1)$ はバックグラウンドにノイズ成分 $(=1)$ が 付加されていると解釈する，ノイズとは，各画素を読ま せるときの信号の変動, 各々の画素位置に対応する検 出感度の変動やバックグラウンド成分の差(変動)などの あらゆる変動要因を含んでいるが，本研究ではバックグ ラウンドに変動を与える成分のみを問題にする，以下の 記述では，このような状態(バックグラウンド+ノイズ) をノイズと記述する. 提案する計数手法は変動に着目し た計数法であるので, 黒点候補には真の黒点とノイズ が含まれる。

1-2-2では黒点をノイズと分離して計数するために, ノイズよりも高いデイジタル值の変化を与える状況と画 素を超えて等方的に分布する状況を考慮する，さらに， 1-2-3では, 重複カウント(黒点候補位置が隣接する場 合)を排除して 1 個の黒点を計数する方法を示す.

\section{1-2-1 黒点候補位置の検出方法}

Fig. 2 に, 黒点を生じている画素とその周辺の画素の 概念図を示す，座標 XY は，左上を基準にして右方向 および下方向に定義した，さらに，着目する 1 個の画素 を region of interest(ROI) と呼び，その中心の座標を $(X, Y)=(i, j)$ とした(黒く塗りつぶした領域).ささらに, こ の ROI を取り囲む 8 個の画素を ROI+1 領域と定義し,

同様に, ROI+1 領域を囲む 16 個の画素を ROI+2 領域 と定義する.

$\mathrm{ROI}+1$ 領域に対して ROI $(i, j)$ のみが高いデイジタル 值を示す理想的な場合には，以下の条件式に対してす ベて真(true)が得られる. 


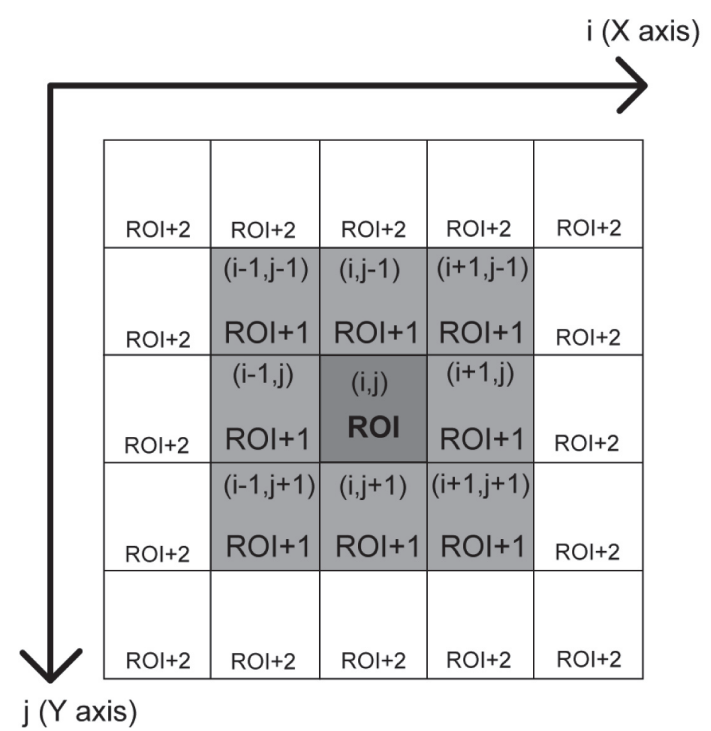

Fig. 2 Definition of the coordination system for region of interest (ROI).

条件 1 (X 方向) :

$D(i, j)-D(i-1, j)>d$ かつ $D(i+1, j)-D(i, j)<(-d)$

条件 2(Y 方向) :

$D(i, j)-D(i, j-1)>d$ かつ $D(i, j+1)-D(i, j)<(-d)$

条件 3(左上 $\rightarrow$ 右下)：

$D(i, j)-D(i-1, j-1)>d$ かつ $D(i+1, j+1)-D(i, j)<(-d)$

条件 4(右上 $\rightarrow$ 左下)：

$D(i, j)-D(i+1, j-1)>d$ かつ $D(i-1, j+1)-D(i, j)<(-d)$

$D(i, j)$ は ROI の座標 $(i, j)$ のディジタル值であり,$d$ (discrimination level=discri)は $0,1, \cdots$ などの整数值を 取るしきい值である。この論理は，一次元スペクトルの ピーク位置を求める際に微分を行う方法 ${ }^{5}$ を二次元に拡 張し, 斜め方向の判定 (条件 3 および4)を加えたもので ある。

実際の検出判定では, 条件 1 4 のうち任意の 3 個 (項目)が true を与えれば黒点候補として検出 (=1 カウン ト)した。この方法を Fig. 1(a)の範囲に適用すると, 右 上のディジタル值が 234,287 , 左下の 273,206 および 84 の画素が黒点候補として検出される.

\section{1-2-2 黒点候補位置の判定方法}

上述した判定式(discri=0)だけではノイズを除去でき ないので, 以下の二つのパラメータを検討した.
1)Discri を上げる

2)9 個の画素(“ROI”+"ROI+1”)のディジタル值の和を計 算する

RI はノイズに比べ大きなディジタル值の差を与える と考えられる，1）によって discri を大きな值に設定する ことで，例えばバックグラウンド +1 という小さな変動 を与えるノイズを排除することが可能である，また，2） で黒点候補の周辺部分を含むデイジタル值の和を計算 することで，画素を超えて分布する黒点成分を 1 画素 に特異的に表れるノイズと分離する試みである。ここ で, 黒点候補の検出座標を $(i, j)$ としたとき, この座標 を中心とした $3 \times 3$ pixel のディジタル值 $D$ の和(sum value)は以下の式で与えられる.

sum value $=\sum_{s=-1}^{1} \sum_{p=-1}^{1} D(i+s, j+p)$

上記二つのパラメータ (discri 掠よび sum value)を変 更して，黒点の検出結果がどのように変化するのか調 べた，本手法を用いて黒点候補位置を正しく再現でき るかどうかは，実際に放射能污染が確認されたIP の 100×100 pixelの領域を拡大し，プログラムで計数した 座標と実際の画像を比較した。

\section{1-2-3 黒点の計数方法}

上述した論理によって黒点候補を検出したときに，あ る黒点候補と異なる黒点候補が隣接 $(\mathrm{ROI}+1$ に他の黒点 候補が存在)した場合には，これらをまとめて 1 個の黒 点と定義した。すなわち，1-2-2 までの判定ですべての 黒点候補を拾い上げ, ROI+1 の範囲に隣接する割合(重 複カウントの計数)を求め, 前者から後者を引くことで 求めた真の計数值を求めた.

重複カウントの計数は以下の方法で求めた.

a) 1-2-2 までの判定で求めた黒点候補位置のすべての座 標 $(i, j)$ をリストデータ形式で出力する。ここでいうリス トデータとは, $\left\{\left(i_{1}, j_{1}\right),\left(i_{2}, j_{2}\right), \cdots,\left(i_{n}, j_{n}\right)\right\}$ という $n$ 個の黒 点候補座標を含む行列である。

b) 上記のリストデータからある黒点座標を選び，その周 辺座標 $(\mathrm{ROI}+1)$ のリストデー夕 $\{(i-1, j-1),(i, j-1), \cdots$, $(i+1, j+1)\}$ を作成する.

c)a）で生成した黒点候補位置のリストデー夕に，b)で生 成した座標がいくつ含まれるかをカウントし，この操作 をa）の黒点候補位置のリストに含まれるすべての座標 について行う.

d)c)の操作で計数したカウントの $1 / 2$ の值を重複カウン トの計数とする.

この手法を Fig. 1 の範囲に適用すると，右上の 234 と 287 で 1 カウント, 左下の 273 と 206 で 1 カウントが 

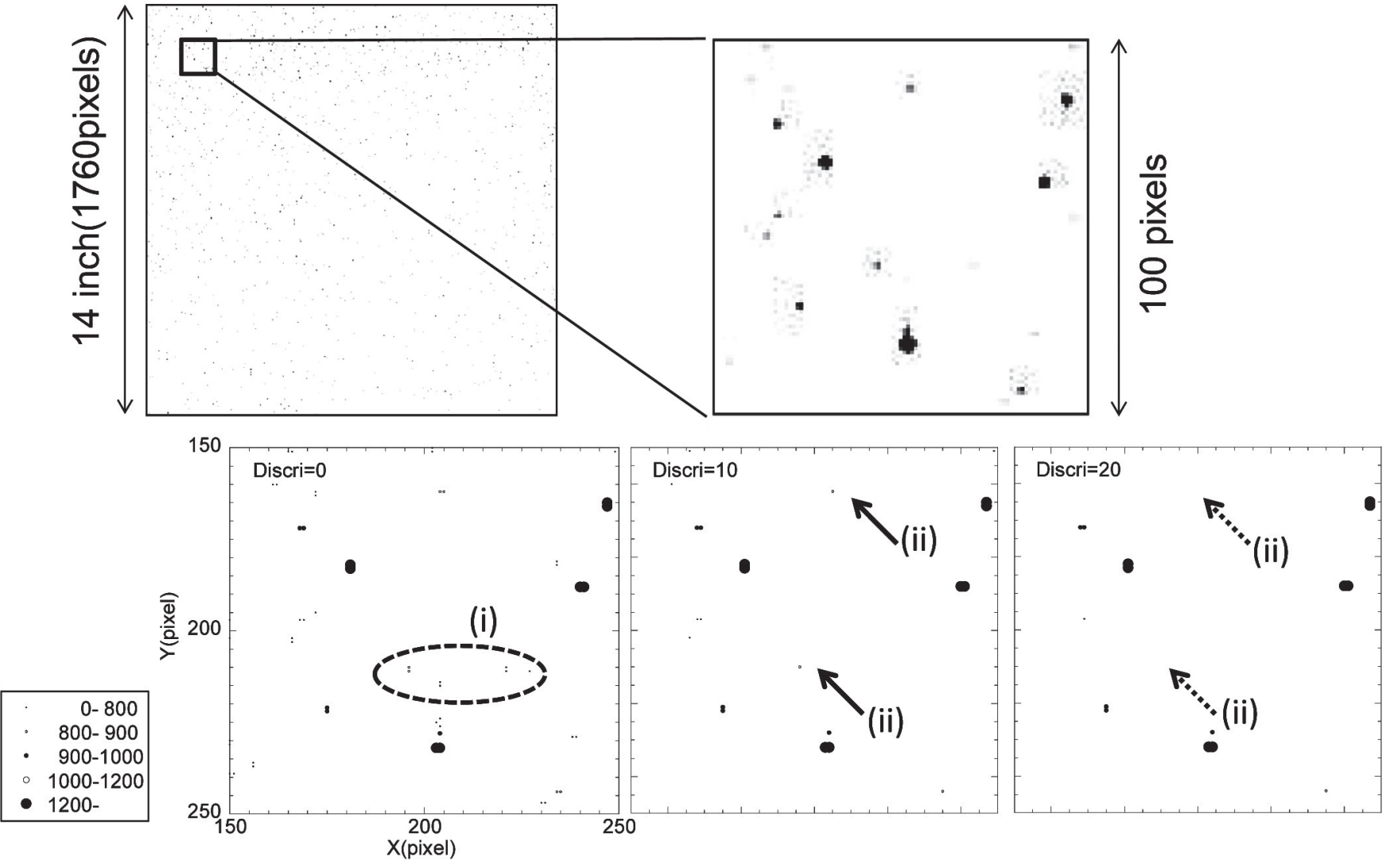

Fig. 3 Comparisons between the measured image (a) and deduced maps of the black spots (b)-(d).

\begin{tabular}{c|c|c}
\multicolumn{4}{c}{$a$} \\
\hline$b$ & $c$ & $d$
\end{tabular}

得られる. 左下の 84 の画素はノイズであるが, ノイズ の分離を行っていない場合はこの画素も 1 カウントとし て計数される.

\section{1-3＼cjkstart重複カウントのシミュレーション}

1-2-3 で考慮した重複カウントは，異なった 2 個の RI による信号，もしくは 1 個の RI が 2 個の隣接するピク セルの中間付近に付着してできた信号のいずれかが原 因となっている。そこで，モンテカルロシミュレーショ ンによって，異なる RIが ROI+1 に隣接する確率を計算 した。

計算では， $1760 \times 1760$ の行列を用意し，乱数を用い てランダムにRIを配置した，すなわち，Randを0〜1 までの実数を生成する乱数とした場合，X座標は Rand $\times 1759+1$ (整数部分を採用)で計算し，さらに別の独 立な乱数を生成してY 座標も計算した。決定した座標 に従って，あらかじめ用意しておいた $1760 \times 1760$ の行 列に「1」という仮想的な值を入力し，この操作を粒子数 が1000回, 2500 回, 5000 回, 7500 回, 10000 回 の ループ計算によって繰り返した。このシミュレーション で生成した行列を 1-2で示した方法で解析した。

\section{2. 結 果}

提案した手法を IP の一部 $(100 \times 100$ pixel)に対して適 用し，1-2-1 で検出した黒点候補位置が，1-2-2で定め た discri や sum valueによってどのように変化するかを 確かめた結果を以下に示す. Fig. 3 は本手法で判定した 黒点候補位置の座標と実測画像を比較した結果であ る. Fig. 3(a) が実測画像で, (b)〜 (d) は discri が 0 , 10, 20 に対応する判定方法で求めた画像である，用い た画像のバックグラウンドはディジタル值が 83 近傍で あると考えられるので，ノイズに相当する 9 個の画素内 におけるディジタル值の和は, 750 近傍 $(83 \times 9$ pixel)で あることが想定される，そこで， sum value を検討する ために Fig. 3(b)〜 (d) では，それぞれ sum value が 0 800，800 900，900 1000，1000 1200，1200 以上で の場合分けをして表示した。これらの場合分けに対し て得られた黒点候補位置のカウント(detected counts)を Table 1 にまとめた. Discri が $0 て ゙$ sum value が 0 ８00 のデー夕は 36 個の計数をしているが, discriを 10 に上 げると 6 個に減り，さらにdiscri を 20 に上げると 1 個 となったままた，強い放射能のRIに対応する sum value が 1200 を超える黒点の数は, discriの值に関係な く 8 個の計数をした. Table 1 には, これらの計数に対 
Table 1 Relationship between parameters (discri and Sum value) and counting results of detected positions of the black spots

\begin{tabular}{|c|c|c|c|c|c|c|}
\hline \multirow{3}{*}{$\begin{array}{l}\text { Selection by } \\
\text { sum value }\end{array}$} & \multicolumn{6}{|c|}{ Counts of black spots } \\
\hline & \multicolumn{2}{|c|}{ Discri=0 [Fig.3(b)] } & \multicolumn{2}{|c|}{ Discri=10 [Fig.3(c)] } & \multicolumn{2}{|c|}{ Discri=20 [Fig.3(d)] } \\
\hline & Detected counts ${ }^{\# 1}$ & Net counts ${ }^{\# 2}$ & Detected counts ${ }^{\# 1}$ & Net counts ${ }^{\# 2}$ & Detected counts ${ }^{\# 1}$ & Net counts $\# 2$ \\
\hline $0-800$ & $36(13)$ & 23 & $6(1)$ & 5 & $1(0)$ & 1 \\
\hline $800-900$ & $6(3)$ & 3 & $3(0)$ & 3 & $1(0)$ & 1 \\
\hline $900-1000$ & $5(2)$ & 3 & $5(2)$ & 3 & $5(2)$ & 3 \\
\hline $1000-1200$ & $0(0)$ & 0 & $0(0)$ & 0 & $0(0)$ & 0 \\
\hline $1200-$ & $8(4)$ & 4 & $8(4)$ & 4 & $8(4)$ & 4 \\
\hline
\end{tabular}

${ }^{\# 1}$ The parenthetical numbers indicate overlapping counts.

${ }^{\# 2}$ The net counts are obtained by subtracting the overlapping counts from the detected ones.

Table 2 Summary of counted black spots

\begin{tabular}{cccc}
\hline \hline Selection by sum value & Detected counts & Overlapping counts & Net counts \\
\hline$>800$ & 1466 & 595 & 871 \\
$>900$ & 726 & 330 & 396 \\
$>1000$ & 523 & 239 & 284 \\
$>1200$ & 329 & 151 & 178 \\
\hline
\end{tabular}

These data were obtained by applying our method (discri=10) to whole of the IP.

して, 1-2-3の判定を行い重複カウント(overlapping counts)の計数を求め, 検出されたカウントから重複カ ウントを引くことで真のカウント(net counts)を計算した 結果も併せて示した.

提案した手法を IP 全体(1760×1760 pixel：全領域)に 対して適用し, discriが10のときに得られた黒点の計 数結果を Table 2 にまとめた. Sum value を 800 以上, 900 以上, 1000 以上， 1200 以上と変化させたときの黒 点の計数は 871 カウント, 396 カウント, 284 カウント, 178 カウントであった.

モンテカルロシミュレーションによって得られた重複 カウントのシミュレーション結果を Fig. 4 に示す。横軸 は仮定した粒子数, 縦軸は隣接する画素に異なる粒子 が配置される確率である。粒子数 1000 のときは $0.16 \%$ の画素が隣接していたが，粒子数を増していくと確率 が増していき, 粒子数 10000 のときは $1.3 \%$ 程度まで増 加することを示している。

\section{3. 考 察}

\section{3-1 Discri と sum value の調整}

まず, discriについて考察する。ノイ゙とバックグラ ウンドの変動(差)よりも大きな discri を設定することで ノイズの計数を抑制し, 結果としてノイズと RI の信号 を分離できると考える. Sum value が 750 近傍 $(83 \times 9)$ の データはノイズとバックグラウンドによって構成されて

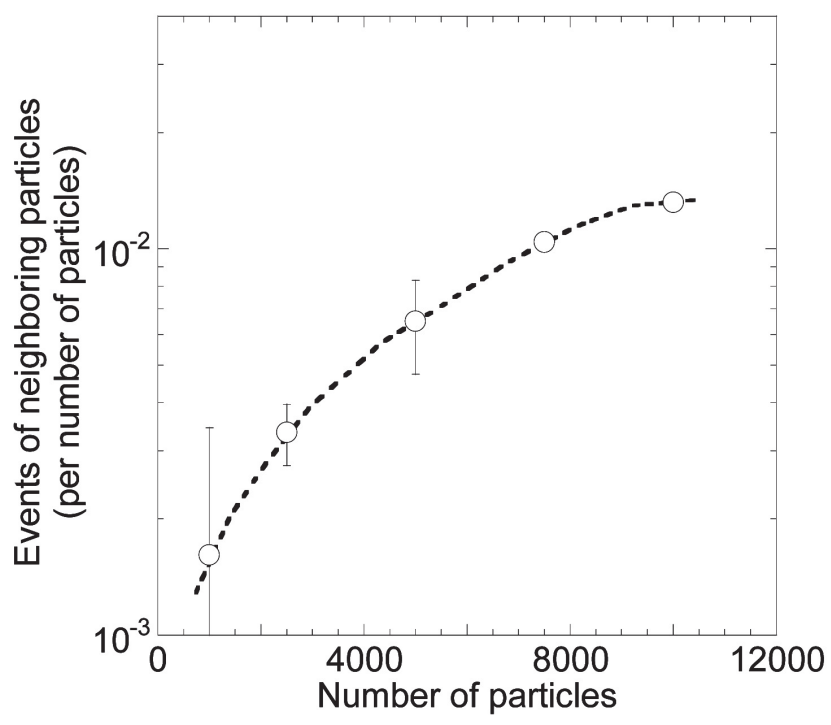

Fig. 4 Simulated result of the provability in which the different two RI were adhered onto the neighboring two pixels. These simulations were applied to a $1760 \times 1760$ area.

いると考えられるので, sum value が 800 以下のデー夕 の再現度合いが視覚評価の一つの指標になる. Table 1 において sum value が 0 800の行に着目すると, discri を 0 から 10，20まで上げることで黒点候補位置の計数 が 36 カウント，6カウント，1カウントと変化してい る。これらのカウントに対応する黒点は, 例えば Fig. 3 (b)〜 (d)の判定画像中の(i)領域で顕著に見られる。す 
なわち, Fig. 3(b)の(i)領域には sum value が 0 ８00の デー夕が多く含まれるが，(d)には全く含まれていな い.これらのデー夕はFig. 3(a) 上では観測されていな いので，計数しないことが望ましい，一方， discriを上 げ過ぎると本来黒点として計数しなければいけない データを数え落としてしまうことが予想される．Table 1 の sum value が 800 900 の行での黒点候補位置のカウ ントは，ノイズぎりぎりの黒点が含まれている，Discri を 0 から 10,20 まで上げて計数の変化を見ると 6 カウ ント， 3 カウント， 1 カウントと減少している。これらの 計数に対応する点は Fig. 3 の (ii) 領域に存在している が，Fig. 3(b) 拉よび(c)では対応する点が見られるもの の, Fig. 3(d)では候補位置として認識できていない. Fig. 3(a)の画像には (ii) 領域に黒点が観測されているこ とから，ここで扱った画像[Fig. 3(a)]を再現する discri の最適值は 0 から 20 の間にあることがわかる.

ここで着目すべき点は, discriを上げると重複カウン 卜を減らす効果があることである。 Table 1 の sum value が 800 900の行での重複カウントは, discriを 0 から 10，20 まで増加させると， 3 カウント，0 カウント，0カ ウントと変化し, discriを上げると重複カウントを減ら す効果があることを示している.

次に, sum valueについて考察する. Sum valueを導 入することで，ノイズを抑制し，RIの強度によって弁別 をした計数ができると考える. Table 1 に扔いて sum value が 1200 を超える黒点の候補位置は, discri の值に かかわらず 8 カウントを計数している，ノイズによる変 動とバックグラウンドだけで 9 個の画素を構成している 場合は, sum value が750 近傍であるので, sum value が 1200 を超える黒点候補位置にはノイズは含まれな い. 対応する黒点の位置は, Fig. 3(b)〜 (d)のいずれの 中でも黒丸が 8 個確認でき, これらの黒点候補位置は Fig. 3(a)の観測された画像中の強い RI に対応する黒点 とも一致している。このように, sum value の大きな黒 点だけを選択すれば，強い放射能の RI に対応する黒点 を選び，ノイズとの分離ができる。これらの黒丸は 2 個 の黒点候補で 1 個の黒点を形成しているが，このことに 関しては後ほど考察する。

上記に示したように, discri と sum value は黒点とノ イズを分離する有効なパラメータであることがわかる. どの程度の sum value を与えたときに黒点と見なすか は，画像や用途によって異なる。しかし，今回の画像 では少なくとも discriを 10 程度に選ぶことで，黒点候 補中のノイズを減少させ，黒点の現れている画像と視 覚的に一致する黒点候補位置を推定できることがわ かった。

\section{3-2 重複カウントと黒点の計数について}

隣接する 2 個の画素に強い放射能の RI が付着して いる場合を考える. CR システムのデイジタル出力は線 量 $(\propto$ 放射能 $\times$ 時間) と対数の関係にあるので ，強い放 射能の RI ほど隣接する 2 個の画素のディジタル值は同 程度のディジタル值を出力し, 結果として 1-2-1 で示す 条件 1〜4のうちどれかが偽(false) になる。このような 黒点を確実に計数するために，条件 1４のうち任意の 3 個が true を与えれば黒点候補として認定している。こ の場合, 2 個の画素に大きなディジタル值があるので, 2 個の黑点候補が得られる。仮に, 条件 1 から 4 のす べてが true を返したときに黒点として判定する論理を 組んだ場合は，上記のような 2 個の画素に同じデイジ夕 ル值を与える黒点は判定されず，強い放射能の黒点ほ ど数え落とすという状況が考えられる。 これが，1-2-1 で示した判定手法の根拠である。これらを Table 3 にま とめた。われわれの判定手法では 1 個もしくは 2 個の隣 接する画素が黒点候補として検出される場合を対象に している。一方， 4 個もしくは 3 個の画素に同程度の ディジタル值が付与された場合は，1-2-1で説明した判 定では 3 個もしくは 2 個の false が返されるので，黒点 として検出されない。これらの事象は今回の画像には 1 例も観測されなかったので，これらの事象が起こる確率 は非常に小さいと推測できる。 なぜなら，3 個の画素に 等しい黒点候補をもたせるような RI の付着位置は物理 的には存在せず，4 個の画素の中心部に RI が付着する 可能性は 2 個の画素の境界付近に RI が付着する確率 よりも格段に少ないからである.

Table 2 に抢いて黒点候補位置のカウントと重複カウ ントを調べると, sum value が低い場合は 40\%ほどが重 複しているのに対して, sum value が高い場合は 50\%近 くのカウントが重複していることがわかる。これらの結 果は, 強い放射能の RI に起因する黒点は 2 個程度の黒 点候補で 1 個の黒点を形成していることを意味してい る. 実際に, Fig. 1 で示した例では, 右上の黒点はディ ジタル值が 234 と 287 の画素が隣接した黒点候補と なって扔り, 左下の黒点も 273 と206の画素が隣接し ている. また, Fig. 3 で示した例でも sum value が 1200 を超える黒点は 2 個の黒点候補位置で 1 カウントになっ ている。これらのデータだけでは，1個の RIに起因す る黒点が 2 個と重複して計数される場合と，2 個の RI が隣接する現象は区別ができない，そこで，モンテカル ロシミュレーションを援用した議論を以下に行う。

モンテカルロシミュレーションによって得られた重複 カウントの結果 (Fig. 4)を見ると 8000 個の粒子が一様に ばらまかれているような状況でも隣接する確率はわずか 
Table 3 Relationship between ROI positions (detected positions) in the black spots and availabilities of our method

\begin{tabular}{|c|c|c|}
\hline Type of black spots counts ${ }^{\# 1}$ & Can be detected by our method & Observed \\
\hline & $\mathrm{OK}$ & Many \\
\hline & OK & Approximately half of detected counts \\
\hline & Impossible & None \\
\hline & Impossible & None \\
\hline
\end{tabular}

${ }^{\# 1}$ The shaded portions mean regions which are considered to be detected positions of black spots.

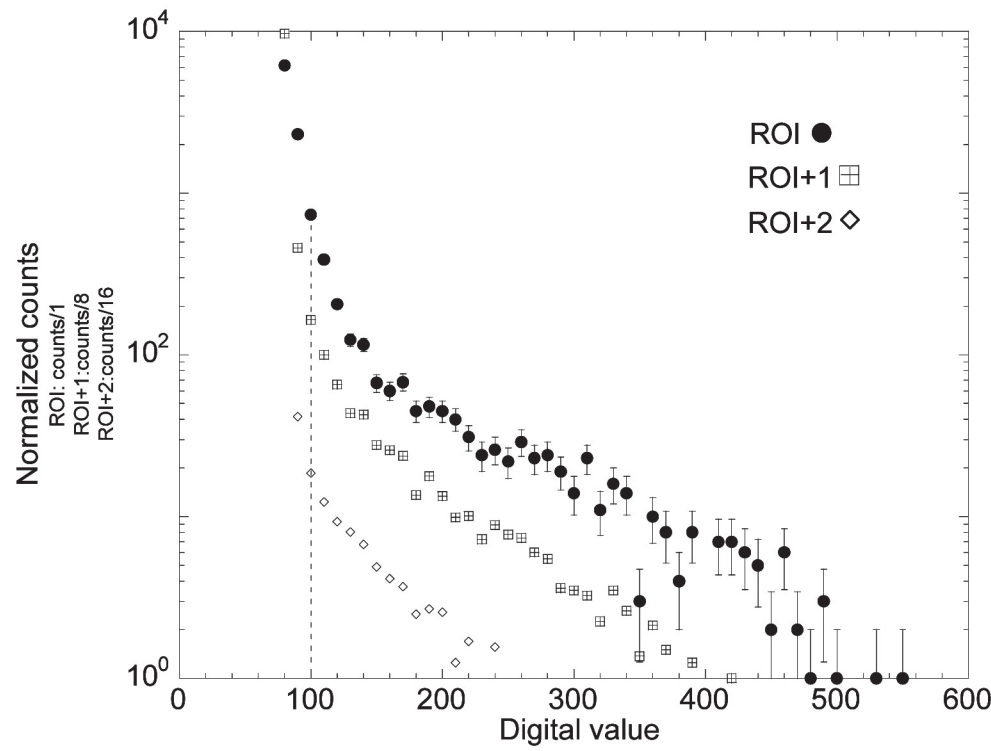

Fig. 5 Histogram of the digital values in the ROI, and around the ROI (ROI+1, ROI+2).

$1 \%$ 程度である.この值は上記の実測とは大きくかけ離 れている。すなわち，実測されたデータの重複カウント は独立した 2 個の RI に起因するのではなく，ほとんど の場合，1個の RI に起因することが考えられる。

\section{3-3 黒点領域の設定について}

Fig. 5 の黑丸のプロットは, discri が 0 として黒点候 補の検出を行い, その黒点(ROI)のディジタル值の頻度 分布を計算したものである。データの誤差には, 統計 誤差(カウントのルート)を付けている。デイジタル值が 80〜90に対応するカウントは 6199 カウントあり，ディ ジタル值が 90〜100 に対応するカウントは 2311 カウン トであった。一方で，ディジタル值が 100〜 110 に対応
するカウントは 736 カウント, デイジタル值が 110～120 に対応するカウントは 390 カウントであるので，ディジ 夕ル值 100 を境に，計数が大きく変化していることがわ かる．黑丸に対応するプロットは黒点およびノイズを含 む黒点候補として計数されているので，ディジタル值が 100 以下に対応する計数はノイズに起因していると考え られる。言い換えれば,ノイズの最大值は100 近傍の ディジタル值であると考えることができる。そこで, ディジタル值 100 以下の画素をノイズと考えて以下の 議論を行う.

Fig. 5 の四角のプロットは, Fig. 2 で示した ROI+1の 領域(Fig. 2 では灰色で示した領域)について, ROI を取 り囲む 8 個の画素が示すディジタル值のヒストグラムを 
計算したものである。黑丸との相対的な比較が行えるよ うに，縦軸のカウントは 8 で除してある. この分布関数 もデイジタル值が 100 以上の部分が約 400 まで存在す ることから，着目したROIに隣接するROI+1の画素も 若干黒くなっていることが判断できる. Fig. 5 のダイヤ 印のプロットは，ROI+2の領域(Fig. 2 では白抜きの四 角で示した領域)のヒストグラムであり, 縦軸のカウント は 16 で除してある。このヒストグラムはほぼノイズのカ ウントで占められていると考えられる.

このことを定量的に示すためにディジタル值が 100 以上となる個数を計数すると, ROI 領域では 2296 カウ ント, ROI+1 領域では 663 カウント, そして ROI+2 領 域では 84.9 カウントであった. Fig. 5 のグラフの面積 $(=$ 黒点候補として計数された ROI の画素数) は 10929 力 ウントであるので, ディジタル值が 100 以上となる割合 は, ROI 領域では $21 \%(=2296 / 10929 \times 100), \mathrm{ROI}+1$ 領 域では 6\%，そして ROI+2 領域では $0.7 \%$ でった。す なわち，黒点が ROI+2 領域に影響を及ぼす割合は無視 できるほど小さいので，黒点候補を含む 9 個の画素 （ROI およびROI+1 領域：3×3 pixel）を黒点の判定領域 と定義すれば十分である。これが，1-2-2で示した判定 手法の根拠である.

上記の議論では ROI+1 までの領域を考慮すれば黒点 の領域を設定するのに十分であることを示し，3-2 では 重複カウントが半数近く含まれる場合があることを示し た。このことは, 黒点の影響が及ぶ領域はほとんどの場 合 ROI+1 であり，その中に黒点候補となる 2 個の画素 が隣接していることを示している.

\section{3-4 本手法の応用}

本手法を用いることで，除染率を評価することや，ど の程度の RI が IP のどこに付着しているかを推定する ことが可能である。除染率を求める場合は, discri と sum value をある程度高めに設定しておいて，除染の前 後でのカウントの変化を調べる。今回の画像の場合は sum value が 1200 以上, discri を 10 に設定すると, 黒 点の計数值は 178 カウント (Table 2)なので, 除染の前 後で 178 カウントがどのように変化したかを調べる方法 が有力である.

一方，どの程度の RI でIPが污染されているかを評 価するためには，ノイズとの境界付近まで判定基準を 下げて黒点位置を計数することが望ましい. 大切なこと は，ノイズ近傍までを対象として黒点位置を探すことで
ある，仮に sum value が 1200 以上のデータだけを対象 とした場合は, 得られた RI の放射能は過小評価になっ てしまう。このように，用途によっても discriや sum value の設定の仕方は変わってくるが, それらを適切に 設定することで黒点計数が可能となる.

本手法のポイントは, RI の個数に対応するような黒 点の計数法を考案したことである. 従来手法のように, 適切なしきい值を用いた 2 值化処理や膨張・収縮処理, ラベリング処理などの画像処理技術を応用して，その しきい值以上の画素を計数することでも付着した RIの 数に比例した量を評価できる.しかしこの方法では信号 成分もノイズ成分も区別することなく黒点候補を数えて しまう。一方，われわれの手法では等方的に広がる RI を想定して黒点の候補位置を決定し, その位置に対し て sum value や discriなどのパラメータで制御を行って いる.この手法の最大のメリットは, 偶発的に表れるノ イズとの分離性能が良いことである。したがって，除染 率の評価に限らず，ノイズぎりぎりのディジタル值を RI に起因する黒点として認定するには，本論文で提案す る黒点の発生機序に基づいた計数法が適している.

\section{4. 結 論}

RI の黒点発生機序に基づいた概念で，黒点を数える プログラムを開発し, 鹿島労災病院(茨城県)で取得さ れたデータを解析した。本論文で採用した画像におけ る黒点は, 最も高いディジタル值を与える画素とその画 素を囲む 8 個の画素の範囲に限定して広がっているこ とがわかった。そこでまず，着目した画素とその近傍の 合計 9 個の画素 $(3 \times 3$ pixel) に対して黑点候補の検出論 理を考え, 黒点中心候補を検出した. 次に, 着目画素と その周辺画素における各ディジタル值の差と 9 個の画 素内におけるデイジタル值の和を適切に設定すれば, 黒点とノイズを分離できることを示した．以上のことか ら，この方法を用いることで，黒点を数えることが可能 であると考えられる。

\section{謝 辞}

この研究は「CR を用いた環境モニタリング調査班」の メーリングリストによる情報提供をきっかけとして行わ れました，班員の皆さま，朝原正喜氏および平野浩志 氏に感謝いたします。 


\section{参考文献}

1) 平野浩志, 柏樹 力, 斎 政博, 他. $\mathrm{CR}$ を用いた環境モ ニタリング調査研究班の紹介。画像通信 2011; 34(2): 73-76.

2) 西原貞光, 林 裕晃. $X$ 線検出器(イメージングプレート)の 放射能污染に対する効果的な除染方法の提案. 日放技学誌 2011; 67(8): 912-915.

3) 小沼洋治, 林美智子, 林 裕晃, 他. X 線検出器(輝尽性 蛍光体プレート)に付着した放射性同位元素の除染. 日放技
学誌 2012; 68(3): 277-282.

4) Abràmoff MD, Magalhães PJ, Ram SJ. Image processing with ImageJ. Biophoton Int 2004; 11(7): 36-42.

5) Gilmore G, Hemingway JD. Practical gamma-ray spectrometry 2nd Ed. New York: John Wiley \& Sons, Ltd., 2008.

6) 岩崎信之. FCR 画像処理解説書. 東京：富士フイルムメ デイカル株式会社, 2001.

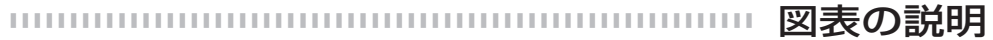

Fig. 1 小さい領域での黒点の例示

Fig. 2 ROI の定義

Fig. 3 測定した黒点画像 (a) と推定した黒点のマップ (b)〜 (d) との比較

Fig. 4 異なるRIが隣接するセルに配置される確率のシミュレーション結果 シミュレーションは 1760×1760 ピクセルの領域で行った.

Fig. 5 ROI およびその周辺の領域(ROI+1，ROI+2)の領域のディジタル值の頻度分布

Table 1 パラメータ(discri および sum value) と黒点候補位置の計数結果 これらは Fig. 3 の画像領域に適用した結果である.

Table 2 黑点の計数結果 これらは，われわれの手法(discri=10)を IP 全体に対して適用した結果得られたものである。

Table 3 黒点中の ROI 位置(検出された位置)とわれわれの手法の有効性の関係 